\title{
The venom and the toxicity of Pelagia noctiluca (Cnidaria: Scyphozoa). A review of three decades of research in Italian laboratories and future perspectives
}

\author{
Rossana Morabito, ${ }^{1}$ Angela Marino, ${ }^{2}$ Giuseppina La Spada, ${ }^{2}$ Luigi Pane, ${ }^{3}$ \\ Gian Luigi Mariottini ${ }^{3}$ \\ ${ }^{1}$ Department of Human and Social Sciences, University of Messina, Messina; ${ }^{2}$ Department of \\ Biological and Environmental Sciences, University of Messina, Messina; ${ }^{3}$ Department of Earth, \\ Environment and Life Sciences, University of Genoa, Genoa, Italy
}

\begin{abstract}
Recurrent outbreaks of Pelagia noctiluca and health problems consequent to stings were recorded during the last decades. This phenomenon forced some Italian University laboratories to study this cnidarian. The first studies concerned the distribution, biochemical composition and morphology of nematocysts of Pelagia noctiluca. The discharge mechanism of nematocysts was defined starting from early 1980s when enzymes, cations, anions, and $\mathrm{pH}$ were observed to have an influence on this process. Notably, trypsin, extreme $\mathrm{pH}$ values, some anions $\left(\mathrm{I}^{-}, \mathrm{Cl}^{-}, \mathrm{SCN}^{-}\right)$, and thioglycolate were seen to induce, while $\mathrm{La}^{3+}$ and $\mathrm{Gd}^{3+}$ to prevent, nematocyst discharge. The discharge of both in situ and isolated nematocyst was found to be $\mathrm{Ca}^{2+}$ dependent. Furthermore, Pelagia noctiluca nematocysts were seen to retain their discharging capacity in distilled water. The toxicological evaluations were carried out mainly using the crude venom from Pelagia noctiluca because, unfortunately, to date the composition of venom remains unknown. Hemolytic and cytotoxic properties of crude venom have been evaluated on erythrocytes and cultured guinea-pig fibrob-
\end{abstract}

Correspondence: Gian Luigi Mariottini, Department of Earth, Environment and Life Sciences, University of Genoa, Viale Benedetto XV 5, 16132 Genoa, Italy.

Tel. +39.010 .3538070 - Fax: +39.010 .3538072$

E-mail: Gian.Luigi.Mariottini@unige.it

Key words: Pelagia noctiluca; Jellyfish; Venom; Toxicity.

Conflict of interest: the authors declare no potential conflict of interest.

Received for publication: 17 June 2015.

Revision received: 11 December 2015.

Accepted for publication: 16 December 2015.

(C) Copyright R. Morabito et al., 2015

Licensee PAGEPress, Italy

Journal of Biological Research 2015; 88:5372

doi:10.4081/jbr.2015.5372

This article is distributed under the terms of the Creative Commons Attribution Noncommercial License (by-nc 3.0) which permits any noncommercial use, distribution, and reproduction in any medium, provided the original author(s) and source are credited. lasts, mouse fibroblasts, and cancer (neuroblastoma) cells. The activity of Pelagia noctiluca venom on other cnidarians has been also assessed. The crude venom induced apoptosis by reactive oxygen species generation and decrease in mitochondrial transmembrane potential, loss of mitochondrial integrity, and alteration of cell membrane permeability. A pore-forming action mechanism on mitochondrial membrane with oxidative damage was also suggested. The protective activity of some compounds against envenomations has been also evaluated. Future challenges will concern the attempts to characterize the venom and to perform a wider screening of cytotoxicity induced to normal and cancer cells.

\section{Introduction}

The toxicity of cnidarians is a matter of concern owing to its impact on several human activities and on public health. Notably, jellyfish outbreaks can affect economic activities, such as bathing, fishing and more generally tourism, with serious consequences to the economic system of some coastal areas. During the last decades jellyfish stinging assumed epidemiological characters previously unknown in the Mediterranean. As a matter of fact, Mediterranean jellyfish have been always known to have scarce toxic potency, and this belief has been the main factor which before the mid 70s - when the first extended outbreaks started to occur $-^{1,2}$ had made research on this subject scarcely attractive.

The poisonousness of cnidarians derives from their specialized venomous capsules, the nematocysts, which are a secretion product of Golgi apparatus and are synthesized by highly specialized cells, the nematocytes. ${ }^{3}$ The nematocysts contain a fine and spiralized thread which is extruded after adequate mechanical or chemical stimulation, acting as a syringe needle and injecting the venom into the prey/attacker.

In humans cnidarian stinging can induce local (eritema, edema, vesicles, dermonecrosis), systemic (cardiotoxic, neurotoxic, myotoxic), but also lethal effects, even though these latter are mainly peculiarity of some Australian cubozoans. The effect of stinging varies according to the responsible species and to the sensitivity of the stung people. Cnidarian venoms are complex compounds and were hypothesized to be produced into tissues and then concentrated into nematocysts. ${ }^{4}$ The damage mechanisms are varied and include damaging of cell membrane with pore formation, and oxidative stress.

The Mauve stinger Pelagia noctiluca Forsskål, 1775 (Cnidaria: Scyphozoa) (Figure 1), is considered the most venomous Mediterranean jellyfish. ${ }^{5,6}$ It is a small pelagic medusa (3-12 cm diam- 
eter of adult umbrella), whose colour varies from pink to brown to violet. It can be observed mainly during spring and summers. The umbrella is phosphorescent. Nematocysts occur mainly in tentacles, but are also observed in oral arms and in the aboral surface of the umbrella where are arranged in radial rows. ${ }^{7,8}$ During the last decades recurrent outbreaks and a lot of health problems to humans, consequent to jellyfish stings, were recorded throughout the Mediterranean coasts. This phenomenon forced some Italian University laboratories (mainly from Genoa, Messina, and Trieste) to study the toxicity of this cnidarian and the impact on human populations. The studies were carried out considering mainly the physiological and toxicological aspects more strictly connected to the venom impact on humans, but covered also other points of view such as some biological (morphology, reproduction, development, tissue composition), and ecological (occurrence, distribution, trophism) aspects.

This paper reviews the research on Pelagia noctiluca venom and toxicity carried our by the Italian University laboratories during the last three decades.

\section{The research by Italian laboratories on Pelagia noctiluca venom}

\section{Nematocyst morphology}

In Italy the first studies about the stinging capsules of cnidarians and their venoms started in early 1980s. The morphology of nematocysts of Pelagia noctiluca has been studied and better defined distinguishing the capsules in different groups on the basis of size, shape and extrusion properties. Quadrifoglio and colleagues ${ }^{9}$ recognized five morphological types of nematocysts (heterotrichous microbasic eurytele, holotrichous isorhiza haploneme type I, atrichous isorhiza haploneme type I, holotrichous isorhiza haploneme type II and atrichous isorhiza haploneme type II) which were classified on the basis of what reported by Mariscal. ${ }^{10}$ Subsequently, ultrastructural studies carried out at the University of Trieste ${ }^{11,12}$ better defined the nematocyst types and allowed to recognize heterotrichous microbasic eurytele, holotrichous 0-isorhiza, heterotrichous isorhiza, atrichous a-isorhiza nematocysts and another type resembling the morphology of microbasic p-mastigophores.

The morphology of stinging capsules of Pelagia noctiluca was subsequently re-examined by Marchini et al. ${ }^{13}$ The nematocysts were grouped into three morphological types: great-spherical nematocysts (group 1), corresponding to the holotrichous isorhiza and large atrichous isorhiza described by Avian and colleagues; ${ }^{11,12}$ smaller/elliptical nematocysts (group 2), corresponding to the heterotrichous microbasic eurytele and the heterotrichous isorhiza described by Avian and colleagues; ${ }^{11,12}$ smallest/elliptical nematocysts (group 3) having protruded operculum.

The undischarged holotrichous-isorhiza nematocyst is shown in Figure 2.

\section{Nematocyst discharge}

The discharge mechanism of Pelagia noctiluca nematocysts was carefully studied starting from early 1980 s when some agents, such as enzymes, cations, anions, as well as $\mathrm{pH}$ were observed to have an influence on this process. Notably, from early 1980s, the research group of the University of Messina observed that trypsin, extreme $\mathrm{pH}$ values $(<2$ and $>11)^{14,15}$ and some anions, in particular $\mathrm{I}^{-}, \mathrm{Cl}^{-}, \mathrm{SO}_{4}{ }^{2-},{ }^{16} \mathrm{SCN}^{-},{ }^{-17}$ as well as thioglycolate, which reduces $-\mathrm{S}-\mathrm{S}-$ bridges,${ }^{18}$ induce nematocyst discharge, while $\mathrm{La}^{3+}$ and $\mathrm{Gd}^{3+}$, the latter known to be a blocker of mechanosensitive ion channels, prevent the discharge of oral arms nematocysts. ${ }^{19} \mathrm{I}^{-}$showed the main effectiveness in promoting discharge, while $\mathrm{Cl}^{-}$and $\mathrm{SO}_{4}{ }^{2-}$ showed less efficacy. ${ }^{16}$ Another paper, in which the effectiveness of Hofmeister anions in promoting discharge was studied, showed that $\mathrm{SO}_{4}{ }^{2-}$ was scarcely effective. ${ }^{17}$ The obtained results allowed to suggest an effect of ions on capsular protein conformation. ${ }^{16}$ Extremely acidic aqueous solutions (pH 1.0-3.5) were seen to induce the collapse of capsular wall of undischarged nematocysts. ${ }^{15}$

Furthermore, nematocyte activation and the discharge in situ of Pelagia noctiluca nematocyte was stated to be a $\mathrm{Ca}^{2+}$ dependent phenomenon, ${ }^{19}$ as previously observed in other cnidarians, such as Calliactis parasitica and Aiptasia mutabilis..$^{20,21}$ Notably, $\mathrm{Ca}^{2+}$ permeable mechanosensitive channels were demonstrated to be involved in the activation of nematocytes ${ }^{19}$ and $\mathrm{Ca}^{2+}$ ions were indicated to act preventing the discharge of isolated nematocysts. ${ }^{14}$

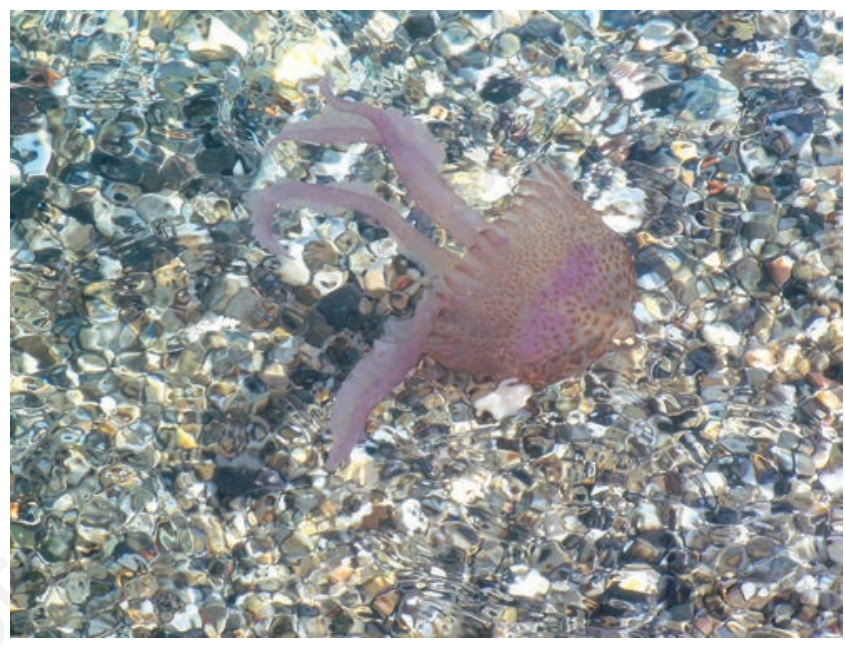

Figure 1. Pelagia noctiluca (Cnidaria: Schyphozoa) photographed in June 2012 along the Eastern Sicily coast.

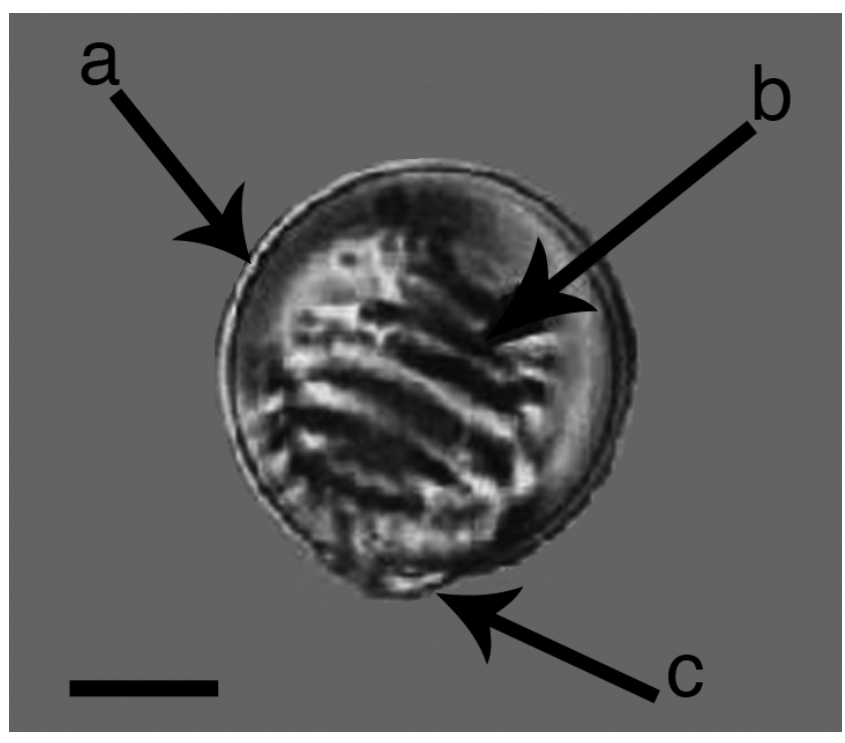

Figure 2. Holotrichous-isorhiza nematocyst isolated from Pelagia noctiluca oral arms: a) nematocyst wall; b) inner coiled tubule; c) operculum. Scale bar: $10 \mu \mathrm{m}$. 
Furthermore, in opposition to what previously known, Pelagia noctiluca nematocysts were seen to retain their discharging capacity in distilled water. ${ }^{14}$

Further research concerned the evaluation of the activity of amino acids, proteins (mucin, albumin, poly-L-lysine, trypsin), sugars and $\mathrm{N}$ acetylate sugars (N-acetyl neuraminic acid, N-acetylgalactosamine, sucrose, glucose, agarose and trehalose), nucleotides (ATP and cAMP) in inducing nematocyte discharge in Pelagia noctiluca oral arms which were treated with these compounds and with mechanical stimulation. The discharge induced by this combined action was greater that that observed after mechanical stimulation alone. Notably, the chemosensitizing effect of sugars, glutathione, nucleotides and mucin was dosedependent effect. ${ }^{22}$

More recent research ${ }^{23}$ reported the evaluation of the activity of local anesthetic lidocaine, alcohols, acetic acid and ammonia in preventing discharge of Pelagia noctiluca nematocysts when induced by chemosensitizers ( $\mathrm{N}$-acetyl neuraminic acid, $\mathrm{N}$-acetyl galactosamine, glutamate, artherenol, carbachol, arginine, glycine, cysteine, mucin, albumin). Excluding lidocaine which induced a slight, non significant, increase of discharge in comparison to the control, all evaluated compounds failed to induce discharge per se and, furthermore, they were able to impair the discharge induced by chemosensitizers. For this reason, the local treatment with lidocaine, acetic acid, ethanol and ammonia was suggested after Pelagia noctiluca stinging.

Morabito et al. ${ }^{24}$ reported that 20 min treatment of oral arms from Pelagia noctiluca with some heavy metals (Zinc, Cadmium, Cobalt, Lanthanum) at 2-10 mM induced a significant and dose-dependent inhibition (irreversible in the case of Lanthanum) of nematocysts discharge. Oxidative events were not involved.

The activity of the combination of mechanical stimulation and different compounds (amino acids, proteins, sugars, N-acetylate sugars, and nucleotides) on discharge was tested on oral arms of Pelagia noctiluca. The discharging resulted more efficient with the combined activity of both mechanical and chemical stimuli and a dose-dependent chemosensitizing mechanism was observed after treatment with nucleotides, mucin, sugars, and glutathione. ${ }^{22}$

Finally, in studies on the effect of $\mathrm{pH}$ changes on the osmotic phase (OP), regulatory volume decrease (RVD) and nematocyte discharge, Pelagia noctiluca nematocysts subjected to hyposmotic shock were seen to expand osmotically and then to regulate the volume within $15 \mathrm{~min}$ at $\mathrm{pH} 7.65$. On the contrary, acidic values compromised the OP $(\mathrm{pH}=6.5)$, reduced or abrogated $\mathrm{RVD}(\mathrm{pH}=4.5)$, and reduced discharge. These results allowed to conclude that environmental changes can have remarkable effects on homeostasis and function of Cnidarians. ${ }^{25}$

Table 1 shows the global data obtained about the activity of some different chemical or physical agents in preventing or promoting nematocyst discharge.

Figure 3 shows a discharged nematocyst of Pelagia noctiluca (Figure 3A), and a particular of the discharged needle (Figure 3B).

\section{Isolation of nematocysts}

The isolation of nematocysts from jellyfish tissues has been attempted with different methods. In our laboratories the first described method is dated from 1984, when Salle ${ }^{26}$ published his paper on discharge mechanism of the nematocysts of Pelagia noctiluca. Subsequently, the treatment with $\mathrm{SCN}^{-}$, the heat dissociation ${ }^{27}$ and the centrifugation and separation by using a Percoll gradient ${ }^{13}$ were utilized. On the whole, SCN- resulted suitable and yielded 90\% intact nematocytes, mainly from tentacles, while from oral arms the yield was lower; unfortunately, heat dissociation was seen to damage the nematocytes and thus resulted unsuitable. ${ }^{27}$

On the basis of the method from Salle $0^{26}$ a quite recent paper, after suspending oral arms for two hours in cold $\left(4^{\circ} \mathrm{C}\right)$ distilled water, was able to detach the jellyfish epiderm from underlying tissues and to induce the osmotic rupture of nematocytes which, as a consequence, causes the delivery of undischarged nematocysts. ${ }^{28}$ After subsequent filtration and centrifugation clean holotrichous isorhiza nematocysts were obtained and utilized for experimental procedures. The conservation of nematocysts was reported to be dependent on temperature (the best results were obtained through freezing) and $\mathrm{pH}$ with neutral values resulting appropriate..$^{29}$

\section{Physiological and biochemical aspects}

Analyses of trace elements carried out on tentacles of Pelagia noctiluca showed that metal content does not differ significantly in different periods. ${ }^{30}$

As concerns the protein content of capsular fluid and capsular wall, in both structures glutamic acid was observed to be the most frequent aminoacid (80\% in proteins of the capsule fluid and $90 \%$ in that of capsule wall). ${ }^{31}$

Preliminary results of HPLC analyses on Pelagia noctiluca crude extracts partially separated by gradient density showed that a noticeable amount of the extract was of protein nature; this result was also confirmed by protein analyses..$^{13}$

Recent results were provided about the mechanisms involved in the regulatory volume decrease (RVD) and in the osmotic phase (OP) after exposition of nematocytes to hyposmotic stress. The abrogation of

Table 1. Induction of nematocyst discharge by different agents.

\begin{tabular}{|c|c|c|}
\hline Agent & yst discharge & Reference \\
\hline Trypsin & + & Salleo et al. ${ }^{14}$ \\
\hline Extreme $\mathrm{pH}$ values $(<2 ;>11)$ & + & Salleo et al. ${ }^{15}$ \\
\hline Acidic $\mathrm{pH}$ values $(6.5,4.5)$ & - & Morabito et al. ${ }^{26}$ \\
\hline $\mathrm{I}^{-}$ & + & Salleo et al. ${ }^{16}$ \\
\hline $\mathrm{Cl}^{-}$ & + & Salleo et al. ${ }^{16}$ \\
\hline $\mathrm{SO}_{4}^{2-}$ & + & Salleo et al. ${ }^{16,17}$ \\
\hline $\mathrm{SCN}^{-}$ & + & Salleo et al..$^{17}$ \\
\hline Thioglycolate & + & Salleo et al. ${ }^{18}$ \\
\hline $\mathrm{La}^{3+}$ & - & Salleo et al. ${ }^{19}$ \\
\hline $\mathrm{Gd}^{3+}$ & - & Salleo et al. ${ }^{19}$ \\
\hline $\mathrm{Ca}^{2+}$ & - & Salleo et al..$^{14}$ \\
\hline Distilled water & - & Salleo et al. ${ }^{14}$ \\
\hline Amino acids & + & Morabito et al. ${ }^{22}$ \\
\hline Proteins & + & Morabito et al. ${ }^{22}$ \\
\hline Sugar and N-acetylate sugar & + & Morabito et al. ${ }^{22}$ \\
\hline Nucleotides & + & Morabito et al. ${ }^{22}$ \\
\hline Lidocaine & - & Morabito et al. ${ }^{23}$ \\
\hline Alcohols & - & Morabito et al. ${ }^{23}$ \\
\hline Acetic acid & - & Morabito et al. ${ }^{23}$ \\
\hline Ammonia & - & Morabito et al. ${ }^{23}$ \\
\hline Chemosensitizer compounds & + & Morabito et al. ${ }^{23}$ \\
\hline Heavy metals & - & Morabito et al. ${ }^{24}$ \\
\hline Mechanical and chemical stimulation ${ }^{*}$ & + & Morabito et al. ${ }^{25}$ \\
\hline
\end{tabular}

*It refers to amino acids, proteins, sugars, N-acetylate sugars, nucleotides. 
OP and of the consequent cell swelling with inhibition of RVD was found to be mediated by a $\mathrm{HgCl}_{2}$-sensitive transport mechanism with effective inhibitory concentrations of $0.1-25 \mathrm{\mu M} \mathrm{HgCl}_{2}{ }^{32}$

Other studies aimed to verify if crude venom (CV) from Pelagia noctiluca may affect RVD of isolated nematocytes from Aiptasia mutabilis (Anthozoan) have shown that the morphology of exposed nematocytes was not damaged by CV, but they did not exhibit RVD. This suggested the occurrence of inhibition on cell membrane ion transport mechanisms involved in RVD induced by CV. ${ }^{33}$

The oxidative stress induced on human erythrocytes by CV from Pelagia noctiluca nematocysts was studied by Morabito and colleagues, ${ }^{34}$ who associated the decrease of $\mathrm{SO}_{4}{ }^{2-}$ uptake and of GSH levels in venom-treated erythrocytes and the increased $\mathrm{Cl}^{-}$dependent $\mathrm{K}^{+}$efflux to the oxidative stress induced by $\mathrm{CV}$, which therefore seems to be able to alter cell membrane transport in human erythrocytes.

The exposition of isolated nematocytes from Pelagia noctiluca to heavy metals ( $\mathrm{Cd}, \mathrm{La}, \mathrm{Co}, \mathrm{Cu}, \mathrm{Zn})$ at concentrations included between 100 and $0.1 \mu \mathrm{M}$, was studied in order to evaluate the eventual inhibition of RVD and OP. Co and La inhibited RVD but not OP. $\mathrm{Cu}, \mathrm{Cd}$ and $\mathrm{Zn}$ prevented the OP and the detection of RVD in a dose-dependent way. This study suggested also the possible utilization of cnidarians as models in ecotoxicology. ${ }^{35}$

\section{Toxicological aspects}

The toxicological evaluations have been carried out using the crude venom from Pelagia noctiluca because, unfortunately, to date the composition of venom is not known.

The first experimental toxicological data obtained in Italy were published by the group of the University of Trieste. The irritant effect of preparations of intact nematocysts were tested on hairless mice and on human skin observing erytema and papules in mice after contact, while after intradermal injection erytema, oedema, leukocyte infiltrate and nodular lesions with central necrosis were observed. ${ }^{36}$ Scratch tests carried out on human skin showed transient irritant effects (disappearing after 48-72 hours) with erytema after 30 minutes from contact and pruritus in less than $50 \%$ of cases. ${ }^{37}$

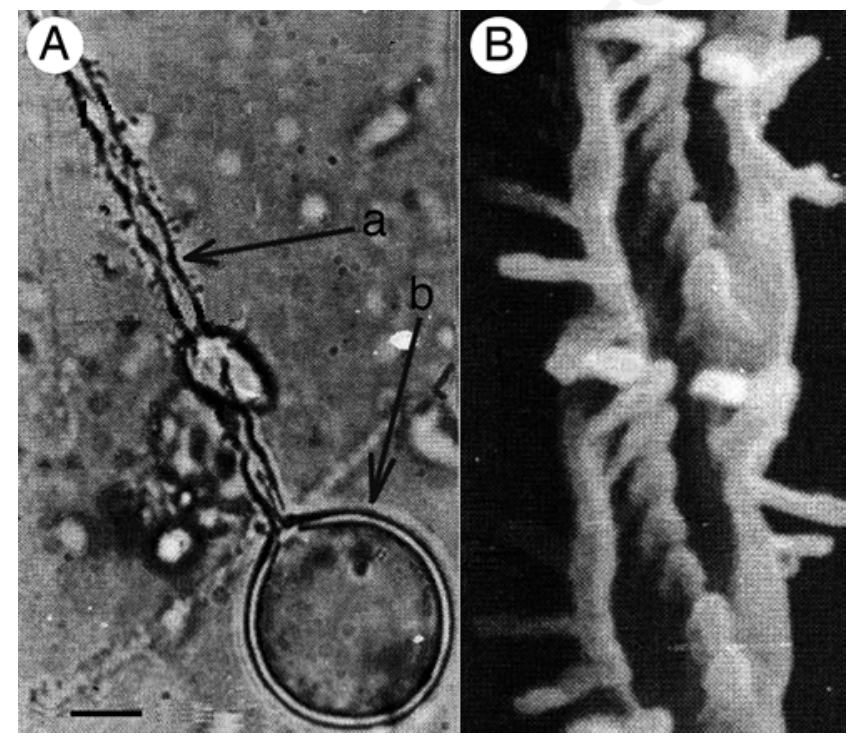

Figure 3. Discharged nematocyst of Pelagia noctiluca (A), and particular of the discharged filament (B). In A) the discharged filament (a) and the nematocyst wall (b) are shown. Scale bar (A): $10 \mu \mathrm{m}$.
Other in vivo evaluations of the activity of $\mathrm{CV}$ from Pelagia noctilu$c a$ were carried out after more that twenty-five years, when Bruschetta et $a l .{ }^{38}$ studied the inflammation and the oxidative stress events induced by $\mathrm{CV}$ in rats showing that Pelagia noctiluca CV enhances ROS formation. Increasing doses significantly reduced blood pressure and increased mortality. Furthermore, plasma levels of some liver parameters, such as ALT, AST, bilirubin, and alkaline phosphatase increased after treatment indicating development of hepatocellular injury. Similarly, lipase and amylase levels (pancreatic injury), and plasmatic creatinine concentration (renal dysfunction) increased. Lung and gut biopsies showed marked inflammation and cellular infiltration. The levels of inhibitor of kappa B (IкB- $\alpha$ ) were observed to be reduced in lung and gut, while NF-кB p65 expression increased. In addition, the expression of the pro-inflammatory protein cyclooxygenase (COX-2), which is known to be a key-enzyme in the conversion of arachidonic acid to prostaglandins, increased in lung and gut. Pro-apoptotic transcriptional changes (up-regulation of Bax and down-regulation of antiapoptotic Bcl-2) were also identified. In all these cases, the subsequent treatment with the potent antioxidant Tempol reduced the effects of CV.

Both hemolytic and cytotoxic properties of of CV from Pelagia noctiluca have been evaluated on erythrocytes, and on cultured guinea-pig fibroblasts, mouse fibroblasts, and cancer (neuroblastoma) cells, respectively, to elucidate the mechanism of action of venom on mammalian cells.,39-43 In addition, the activity of crude venom on other cnidarians has been assessed.

When evaluated by trypan blue dye exclusion, neutral red assay and colony forming efficiency CV induced remarkable and fast cytotoxicity with severe survival decrease on cultured V79 cells in both short-term ${ }^{40}$ and long-term ${ }^{39}$ tests. Cell growth decrease of 45,61 , and $38 \%$ was observed after treatment with 15,000, 30,000, and 150,000 nematocysts/mL, respectively. On the contrary, effects on DNA were not emphasized and the increase of ATP levels after 1 hour treatment and a subsequent decrease was observed. ${ }^{40}$ Higher nematocyst concentrations in CV $(120,000,240,000,480,000 \mathrm{nem} . / \mathrm{mL})$ caused strong cytotoxicity to L929 cells (cell survival 99, 94, 71\%, respectively) after 20 min. $^{44}$ Subsequently, Morabito et al..$^{41}$ observed that $0.05-0.5 \mu \mathrm{g} / \mathrm{mL}$ of $\mathrm{CV}$ induced dose- and time-dependent production of intracellular reactive oxygen species (ROS) which caused oxidative stress and changes in mitochondrial transmembrane potential, and affected cell viability of human neuroblastoma SH-SY5Y cells. The protective properties of an antioxidant, $\mathrm{N}$-acetyl-cysteine, were tested and found to improve cell viability and counteract ROS production.

CV induced hemolysis of chicken and rabbit red blood cells (RBCs) but was ineffective on fish RBCs. CV was also observed to maintain its hemolytic properties after freezing $\left(-20^{\circ} \mathrm{C} ;-80^{\circ} \mathrm{C}\right)$ and lyophilization. ${ }^{28}$ The involvement of a pore-forming mechanism was supposed. ${ }^{45}$ Some osmotic protectants, such as carbohydrates, cations, proteases and antioxidants, were demonstrated to be able to counteract hemolysis induced by $\mathrm{CV}^{46}$

Another recent paper indicated at least four protein fractions of CV responsible for hemolysis induced on fish RBCs. CV from Pelagia noctiluca was seen to affect lysosomal membrane inducing destabilisation. Furthermore, sphyngomyelin inhibits the hemolytic activity. In this research oxidative stress with variation of glutathione (GSH) levels was not recorded. ${ }^{47}$

As concerns research aimed at finding of countermeasures against $P$. noctiluca stinging, using animal models was observed that the administration of melatonin after local envenomation is able to reduce the acute inflammation, accumulation of fluids and lipid peroxidation, thus it was suggested to be useful for the treatment of local acute inflammation by jellyfish stinging. ${ }^{48}$

The protective activity of some compounds has been evaluated with the perspective to provide a tool for prevention of stings. In a recent 
paper, Morabito et al. ${ }^{24}$ reported that the treatment with some heavy metals (Zinc, Cadmium, Cobalt, Lanthanum) at 2-10 mM significantly inhibited the hemolysis induced by CV in a dose-dependent manner, not involving oxidative events. This activity was irreversible in the case of Lanthanum.

Other data showed that $10^{-4}$ to $10^{-5} \mathrm{M}$ lanthanum sulfate protected cells treated with $120.000 \mathrm{~N} / \mathrm{ml} \mathrm{CV}$, suggesting the utilization of this compound in proper preparations. ${ }^{44}$

\section{Conclusions}

It is well known that cnidarian venoms, in spite of their poisonousness, represent a rich source of biologically active compounds. As concerns Pelagia noctiluca, several ecological and toxicological aspects remain to be explained in order to better know the role of this jellyfish in the marine environment and the mechanisms of injury and toxicity to humans.

From the toxicological point of view, the characterization of the venom of Pelagia noctiluca and the careful evaluation of the damaging properties of nematocyst fluid are fundamental aspects in the perspective of the possible utilization of active compounds in the framework of drug discovery. ${ }^{49}$

Future challenges for scientists, and particularly for Italian researchers, will concern the attempts to obtain a better knowledge and, possibly, a characterization of toxic compounds occurring in the crude venom and including a wider screening of the cytotoxicity and hemolytic properties with the double perspective to assess substances able to counteract the damage caused by jellyfish and to utilize their venomous properties in the development of drugs targeted at the treatment of human pathologies.

\section{References}

1. UNEP. Report on Workshop on jellyfish blooms in the Mediterranean, Athens, 31 October - 4 November 1983. Athens, Greece: UNEP; 1984.

2. UNEP. Jellyfish blooms in the Mediterranean. Proceedings of the II Workshop on jellyfish in the Mediterranean Sea. Athens, Greece: UNEP; 1991.

3. Marino A, Morabito R, La Spada G. Physiology of nematocytes. In: Proceedings of the $83^{\text {th }}$ National Congress SIBS, Palermo, Italy, 2425 October 2013; Abstract No.36.

4. Allavena A, Mariottini GL, Carli AM, et al. In vitro evaluation of the cytotoxic, hemolytic and clastogenic activities of Rhizostoma pulmo toxin(s). Toxicon 1998;36:933-6.

5. Mariottini GL, Giacco E, Pane L. The mauve stinger Pelagia noctiluca (Forsskål, 1775). Distribution, ecology, toxicity and epidemiology of stings. A review. Mar Drugs 2008;6:496-513.

6. Mariottini GL, Pane L. Mediterranean jellyfish venoms: a review on Scyphomedusae. Mar Drugs 2010;8:1122-52.

7. Queruel P, Bernard P, Goy J, Dantzer E. Envenimations par la méduse Pelagia noctiluca sur nos côtes méditerranéennes. Presse Med 2000;29:188.

8. Tibballs J. Australian venomous jellyfish, envenomation syndromes, toxins and therapy. Toxicon 2006;48:830-59.

9. Quadrifoglio F, Avian M, Del Negro P, et al. Nematocisti e tossine di Pelagia noctiluca (Forskål). Nova Thalassia 1986;8:155-62.

10. Mariscal RN. Nematocysts. In: Muscatine L, Lenhoff HM, eds. Coelenterate biology. New York, NY: Academic Press Inc.; 1974. pp 129-78.
11. Avian M, Rottini L, Bratina F. Six types of cnidocysts in Pelagia noctiluca identified by means of light scanning electron microscopy and videoanalyzer. MAP Tech Rep Ser 1991;47:217-26.

12. Avian M, Del Negro P, Rottini Sandrini L. A comparative analysis of nematocysts in Pelagia noctiluca and Rhizostoma pulmo from the North Adriatic Sea. Hydrobiologia 1991;216/217:615-21.

13. Marchini B, De Nuccio L, Mazzei M, Mariottini GL. A fast centrifuge method for nematocysts isolation from Pelagia noctiluca Forskål (Scyphozoa). Riv Biol-Biol Forum 2004;97:505-16.

14. Salleo A, La Spada G, Alfa M. Blockage of trypsin-induced discharge of nematocysts of Pelagia noctiluca by $\mathrm{Ca} 2+$. Mol Physiol 1983;3:89-97.

15. Salleo A, La Spada G, Falzea G, Denaro NG. Discharging effects of anions and inhibitory effect of divalent cations on isolated nematocysts of Pelagia noctiluca. Mol Physiol 1984;5:25-34.

16. Salleo A, La Spada G, Falzea G, Denaro MG. pH-induced collapse of the capsular wall in isolated nematocysts of Pelagia noctiluca. Cell Mol Biol 1984;30:91-4.

17. Salleo A, La Spada G, Falzea G, Denaro MG. Discharging effectiveness of lyotropic anions on nematocysts of Pelagia noctiluca. Mol Physiol 1984;6:19-26.

18. Salleo A, La Spada G, Denaro MG, Falzea G. Effects produced by SCN- and thioglycolate on isolated nematocysts of Pelagia noctiluca. Cell Mol Biol 1986;32:661-6.

19. Salleo A, La Spada G, Barbera R. Gadolinium is a powerful blocker of the activation of nematocysts of Pelagia noctiluca. J Exp Biol 1994;187:201-6

20. Santoro G, Salleo A. Cell-to-cell transmission in the activation of in situ nematocytes in acontia of Calliactis parasitica. Experientia 1991;47:701-3.

21. Santoro G, Salleo A. The discharge of in situ nematocysts of the acontia of Aiptasia mutabilis is a Ca2+-induced response. J Exp Biol 1991;156:173-85.

22. Morabito R, Marino A, La Spada G. Nematocytes' activation in Pelagia noctiluca (Cnidaria, Scyphozoa) oral arms. J Comp Physiol A 2012;198:419-26.

23. Morabito R, Marino A, Dossena S, La Spada G. Nematocyst discharge in Pelagia noctiluca (Cnidaria, Scyphozoa) oral arms can be affected by lidocaine, ethanol, ammonia and acetic acid. Toxicon 2014;83:52-8

24. Morabito R, Dossena S, La Spada G, Marino A. Heavy metals affect nematocysts discharge response and biological activity of crude venom in the jellyfish Pelagia noctiluca (Cnidaria, Scyphozoa). Cell Physiol Biochem 2014;34:244-54.

25. Morabito R, Marino A, Lauf PK, et al. Sea water acidification affects osmotic swelling, regulatory volume decrease and discharge in nematocytes of the jellyfish Pelagia noctiluca. Cell Physiol Biochem 2013;32:77-85.

26. Salleo A. Discharge mechanism of the nematocysts of Pelagia noctiluca. In: Bolis L, Zadunaisky J, Gilles R, eds. Toxins, drugs and pollutants in marine animals. Berlin, Germany: Springer Verlag; 1984. pp 63-68.

27. La Spada G, Marino A, Sorrenti G. Pelagia noctiluca "blooming" in the Strait of Messina: preliminary studies on the applicability of two methods for isolating nematocysts. PSZNI Mar Ecol 2002;23(Suppl.1):220-7.

28. Marino A, Crupi R, Rizzo G, et al. The unusual toxicity and stability properties of crude venom from isolated nematocysts of Pelagia noctiluca (Cnidaria, Scyphozoa). Cell Mol Biol 2007;53: 994-1002.

29. Marino A, Crupi R, Musci G, La Spada G. Morphological integrity and toxicological properties of Pelagia noctiluca (Scyphozoa) nematocysts. Chem Ecol 2006;22(Suppl.1):S127-31. 
30. Cimino G, Alfa M, La Spada G. Trace elements in tentacles from the jellyfish Pelagia noctiluca. Mar Pollut Bull 1983;14:197-8.

31. Salleo A, Calabrese L, Barra D, La Spada G. Characterization of protein components of the capsule fluid ad of the capsule wall of the nematocysts of Pelagia noctiluca. Nova Thalassia 1986;8:119-22.

32. Marino A, Morabito R, La Spada G, et al. Evidence for aquaporinmediated water transport in nematocytes of the jellyfish Pelagia noctiluca. Cell Physiol Biochem 2011;28:1211-8.

33. Morabito R, Dossena S, La Spada G, Marino A. Regulatory volume decrease in isolated nematocytes is affected by crude venom from the jellyfish Pelagia noctiluca. J Biol Res - Boll Soc It Biol Sper 2014;87:50-5.

34. Morabito R, Marino A, Romano P, et al. Sulphate and chloridedependent potassium transport in human erythrocytes are affected by crude venom from nematocysts of the jellyfish Pelagia noctiluca. Cell Physiol Biochem 2013;32:86-95.

35. Morabito R, Marino A, La Spada G. Heavy metals affect regulatory volume decrease (RVD) in nematocytes isolated from the jellyfish Pelagia noctiluca. Comp Biochem Phys A 2013;165:199-206.

36. Del Negro P, Sciancalepore M, Mulas G. Studi preliminari sulla dermotossicità da Pelagia noctiluca nell'animale da esperimento. Boll Accad Sc B0 1985/86;14:147.

37. Scarpa C, Kokelj F, Del Negro P, Tubaro A. Valutazione dell'effetto irritante sulla cute umana di una preparazione di nematocisti di Pelagia noctiluca. Ann It Derm Clin Sper 1987;41:337-41.

38. Bruschetta G, Impellizzeri D, Morabito R, et al. Pelagia noctiluca (Scyphozoa) crude venom injection elicits oxidative stress and inflammatory response in rats. Mar Drugs 2014;12:2182-204.

39. Carli A, Mariottini GL, Pane L. Ecological and medical aspects of jellyfish poisoning. In Epidemiological studies related to the environmental quality criteria for bathing waters, shellfish-growing waters and edible marine organisms. Athens, Greece: UNEP; 1995. pp 1-21.

40. Mariottini GL, Sottofattori E, Mazzei M, et al. Cytotoxicity of the venom of Pelagia noctiluca Forskal (Cnidaria: Scyphozoa). Toxicon 2002;40:695-8.

41. Morabito R, Condello S, Currò M, et al. Oxidative stress induced by crude venom from the jellyfish Pelagia noctiluca in neuronal-like differentiated SH-SY5Y cells. Toxicol In Vitro 2012;26:694-9.

42. Mariottini GL, Pane L. Cytotoxic and cytolytic cnidarian venoms. A review on health implications and possible therapeutic applications. Toxins 2014;6:108-51.

43. Mariottini GL. Hemolytic venoms from marine cnidarian jellyfish: an overview. J Venom Res 2014;5:22-32.

44. Mariottini GL, Giacco E, Pane L. Inhibition of the cytotoxicity of Pelagia noctiluca venom by lanthanum sulfate. J Biol Res - Boll Soc It Biol Sper 2010;83:25-8.

45. Marino A, Morabito R, La Spada G. Toxicity of crude venom from the Scyphozoan Pelagia noctiluca. Comp Biochem Phys A 2009;154:30.

46. Marino A, Morabito R, Pizzata T, La Spada G. Effect of various factors on Pelagia noctiluca (Cnidaria, Scyphozoa) crude venominduced haemolysis. Comp Biochem Phys A 2008;151:144-9.

47. Maisano M, Trapani MR, Parrino V, et al. Haemolytic activity and characterization of nematocyst venom from Pelagia noctiluca (Cnidaria: Scyphozoa). Ital J Zool 2013;80:168-76.

48. Marino A, Di Paola R, Crisafulli C, et al. Protective effect of melatonin against the inflammatory response elicited by crude venom from isolated nematocysts of Pelagia noctiluca (Cnidaria, Scyphozoa). J Pineal Res 2009;47:56-69.

49. Mariottini GL, Pane L. The role of Cnidaria in drug discovery. A review on CNS implications and new perspectives. Rec Pat CNS Drug Discov 2013;8:110-22. 